\section{Impact of storage on the physiological quality of soybean seeds after treatment with fungicides and insecticides}

\author{
Luciano Del Bem Junior $^{* 1}$, Jonas Leandro Ferrari ${ }^{1}$ (D) Gustavo Dario ${ }^{2}$, \\ Carlos Gilberto Raetano ${ }^{1}$ iD
}

\begin{abstract}
Chemical seed treatment is a practice that assists in control of pests and pathogens and allows crops to achieve their maximum yield potential. However, the storage period of seeds treated with insecticides and fungicides can affect seed physiological potential. The aim of this study was to evaluate the physiological quality of soybean seeds treated with different fungicides and insecticides after four different storage periods. The experimental design was completely randomized and the treatments were distributed in a $10 \times 4$ factorial arrangement in which the soybean seeds of the cultivar BMX Potência RR were treated with the following phytosanitary products: fipronil + pyraclostrobin + thiophanate-methyl, thiophanate-methyl, carbendazim, carboxin + thiram, imidacloprid + thiodicarb, chlorantraniliprole, thiamethoxam, cyantraniliprole, fipronil, and a control (seeds without chemical treatment), in four replications. The seeds were evaluated at $0,30,60$, and 90 days after the chemical treatment. The following tests were performed: germination, first count of germination, accelerated aging, seedling emergence in sand, seedling emergence speed, and seedling dry matter. The treatment with the carboxin + thiram fungicide mixture provided for adequate physiological quality of the seeds throughout storage. The insecticide thiamethoxam has a negative effect on the physiological quality of soybean seeds that are stored after treatment with it.
\end{abstract}

Index terms: Glycine max (L.) Merrill, germination, vigor, accelerated aging.

\section{Impacto do armazenamento sobre a qualidade fisiológica de sementes} de soja após tratamento com fungicidas e inseticidas

RESUMO: O tratamento químico de sementes é uma prática que auxilia no controle de pragas e patógenos, além de possibilitar à cultura atingir seu potencial máximo de produção. No entanto, o tempo de armazenamento de sementes tratadas com inseticidas e fungicidas pode influenciar sobre o potencial fisiológico das sementes. Assim, esse trabalho objetivou avaliar a qualidade fisiológica de sementes de soja tratadas com fungicidas e inseticidas, sob quatro períodos de armazenamento. $O$ delineamento experimental foi o inteiramente casualizado e os tratamentos distribuídos no esquema fatorial $10 \times 4$, onde sementes de soja da cultivar BMX Potência RR foram tratadas com os seguintes produtos fitossanitários: fipronil + piraclostrobina + tiofanato-metílico, tiofanato-metílico, carbendazin, carboxina + tiram, imidacloprid + thiodicarb, clorantraniliprole, tiametoxam, ciantraniliprole, fipronil e testemunha (sementes sem tratamento químico), em quatro repetições. As avaliações foram realizadas com 0, 30,60 e 90 dias após o tratamento. Foram realizados testes de germinação, primeira contagem do teste de germinação, envelhecimento acelerado, emergência de plântulas em canteiro, velocidade de emergência de plântulas e massa de matéria seca de plântulas. $O$ tratamento com a mistura fungicida carboxina + tiram proporcionou adequada qualidade fisiológica das sementes ao longo do armazenamento. $O$ inseticida tiametoxam tem efeito negativo na qualidade fisiológica das sementes de soja quando armazenadas.

Termos para indexação: Glycine max (L.) Merrill, germinação, vigor, envelhecimento acelerado.
Journal of Seed Science, v.42, e202042037, 2020

http://dx.doi.org/10.1590/ 2317-1545v42236236 


\section{INTRODUCTION}

The use of soybean seeds of high physiological quality is very important in the soybean production system. Common measures such as earlier sowing, the use of a smaller number of seeds per meter, and sowing of seeds over crop residues have become frequent and have come to require seeds with greater vigor to obtain good stand and satisfactory yield (Venkatesh et al., 2018).

In addition to the factors cited above, the occurrence of insects and diseases at the end development stage of the soybean crop can compromise its yield potential. As part of recommended management, the application of phytosanitary products in chemical treatment of seeds avoids the need for reseeding caused by unsatisfactory initial development. Association of this with genetic and biotechnological improvement allows expression of high yield potential (Ferreira et al., 2016). However, in determined situations, some active ingredients or interactions between products can lead to reduction in germination and vigor and, consequently, lower establishment of seedlings resulting of phytotoxicity in the seeds (Taylor and Salanenka, 2012; Alves et al., 2017).

The seed treatment process can be carried out prior to sowing or in the seed industry, in which seeds are treated on the processing line itself (Brzezinski et al., 2017). In both cases, the farmer can choose to store the treated material; however, the products applied may affect the physiological quality of the seeds.

Rocha et al. (2017) evaluated the effect of storage time on the vigor of treated soybean seeds. The authors concluded that longer storage time led to significant reduction in the vigor levels of soybean seeds, for all the treatments. Dan et al. (2010) concluded that there was a decline in the physiological quality of soybean seeds over the storage period after treatment with the insecticides fipronil, carbofuran, thiamethoxam, imidacloprid, acephate, and imidacloprid + thiodicarb. Furthermore, according to the authors, insecticide treatment of soybean seeds should be performed near the time of sowing. Ferreira et al. (2016) concluded that the treatment with fipronil + pyraclostrobin + thiophanatemethyl negatively affected the quality of soybean seeds evaluated after storage to 60 days.

The effect that phytosanitary products applied on the seed have on physiological aspects of the seed over time needs to be evaluated. Thus, the aim of this study was to determine the effect of treatment with fungicides and insecticides on the quality of soybean seeds at different storage periods.

\section{MATERIAL AND METHODS}

The study was conducted in laboratory using a completely randomized experimental design (CRD), with the treatments distributed in a $10 \times 4$ factorial arrangement, the factors consisting of ten soybean seed treatments and four storage periods $(0,30,60$, and 90 days after treatments), in four replications.

The soybean seeds, cultivar BMX Potência, produced in the 2016/2017 crop season were treated with the products and doses described in Table 1, established for $100 \mathrm{~kg}$ of seeds. The seeds treatment were carried out in $1.0 \mathrm{~L}$ plastic bags containing distilled water plus the respective phytosanitary products at doses for $0.5 \mathrm{~kg}$ of seeds, at a mixture rate of $0.6 \mathrm{~L} .100 \mathrm{~kg}^{-1}$ of seeds. After distribution of the treatments throughout the bags, the seeds were transferred to the bags and shaken vigorously, until complete coverage, according to the method proposed by Cunha et al. (2015).

After the treatment, the seeds were placed in the shade at a temperature of approximately $25{ }^{\circ} \mathrm{C}$ for 30 minutes for the product to dry on the seed surface. They were, then placed in multilayered paper bags and stored in a cool, dry chamber (mean temperature of $20 \pm 2{ }^{\circ} \mathrm{C}$ and relative humidity of $45 \%$ ). The quality of the seeds was evaluated at 0 , 30,60 , and 90 days after the treatment.

To evaluate the effects of the treatments on the physiological quality of the seeds the following tests were performed:

Germination (G): performed on four replications of 50 seeds for each treatment. Seeds were placed in rolls of paper towel previously moistened with water in amount of 2.5 times the weight of the dry paper and kept at a temperature of $25^{\circ} \mathrm{C}$. The evaluations were carried out according to the Rules for Seed Testing (Brasil, 2009), and the results were expressed in percentage of normal seedlings. 
Table 1. Characterization of class of use, commercial product name, and active ingredient of fungicides, insecticides, and mixtures, as well as the doses used in treatment of soybean seeds (BMX Potência RR).

\begin{tabular}{|c|c|c|c|c|}
\hline Treatment & Phytosanitary product & Commercial name & $\begin{array}{l}\text { Active ingredient and dose (g a.i. / } \\
100 \mathrm{~kg} \text { of seeds) }\end{array}$ & $\begin{array}{l}\text { Dose ( } \mathrm{mL} \text { of com. product } \\
\quad / 100 \mathrm{~kg} \text { of seeds) }\end{array}$ \\
\hline 1 & -- & Control & -- & -- \\
\hline 2 & Insecticide/Fungicide & Standak Top ${ }^{\circledast}$ & $\begin{array}{l}\text { fipronil }(50)+\text { pyraclostrobin }(5)+ \\
\text { thiophanate-methyl }(45)\end{array}$ & 200 \\
\hline 3 & Fungicide & Cercobin $^{\circledR}$ & thiophanate-methyl (70) & 100 \\
\hline 4 & Fungicide & Hexin $^{\circledast}$ & carbendazim (50) & 100 \\
\hline 5 & Fungicide & Vitavax Tiram $^{\circledR}$ & carboxin $(60)+$ thiram $(60)$ & 300 \\
\hline 6 & Insecticide & Cropstar $^{\circledR}$ & imidacloprid (75) + thiodicarb (225) & 500 \\
\hline 7 & Insecticide & Dermacor ${ }^{\circledast}$ & chlorantraniliprole (62.5) & 100 \\
\hline 8 & Insecticide & Cruiser $^{\circledast}$ & thiamethoxam (105) & 300 \\
\hline 9 & Insecticide & Fortenza ${ }^{\circledR}$ & cyantraniliprole (72) & 120 \\
\hline 10 & Insecticide & Standak ${ }^{\circledR}$ & fipronil (50) & $200^{*}$ \\
\hline
\end{tabular}

* Dose expressed in g of commercial product / $100 \mathrm{~kg}$ of seeds.

First germination count (FGC): performed together with the germination test. The evaluation was performed five days after sowing, counting only the normal seedlings, with results expressed in percentage (Brasil, 2009).

Accelerated aging (AA): a "gerbox" (plastic germination box) with a horizontal metallic screen fixed in the middle of the box was used. Distilled water $(40 \mathrm{~mL})$ was added to the bottom of each box and the seeds of each treatment were distributed on the screen to cover the screen surface, constituting a single layer. Lids were then placed on the boxes containing the seeds and they were placed in a BOD type chamber at $41^{\circ} \mathrm{C}$, where they remained for 48 hours (MarcosFilho, 1999). After that period, the germination test was performed on the seeds, as described above.

Seedling emergence in sand (SES): four replications of 50 seeds per treatment were sown in a sand bed under conditions without climate control, and they were irrigated when necessary. Evaluation was made beginning at emergence of the first seedlings until stabilization of emergence.

Seedling emergence speed (ES): was performed together with the seedling emergence in sand test (described above) in four replications of 50 seeds for each treatment. The emerged seedlings were counted daily from the beginning of emergence (5th day) up to the time of numerical stabilization of the counting (10th day after setting up the test). The results were expressed in the emergence speed index, according to Maguire (1962).

Seedling dry matter weight (SDMW): after the last evaluation of the emergence in sand test, the above ground part of ten plants per replication was cut, maintaining the order of position for all the seedlings, ensuring impartiality in analysis. The samples were placed in a forced air circulation oven at a temperature of $65 \pm 5^{\circ} \mathrm{C}$ for 72 hours and then weighed on a balance $(\mathrm{d}=0.01 \mathrm{~g})$, and values were expressed in grams.

The data obtained were compared regarding normality by the Shapiro-Wilk test $(p \leq 0.05)$. After that, analysis of variance was performed and the mean values of the treatments and of the storage periods were compared by the Scott-Knott test $(p \leq 0.05)$.

\section{RESULTS AND DISCUSSION}

The interaction between the seed treatment and storage time factors were significant for germination, first count of germination, accelerated aging, and seedling emergence in sand.

The results obtained in the germination test indicated that at time zero all the treatments achieved an adequate level of germination for the soybean seeds, with percentages above $80 \%$, the minimum value established as a reference 
by Brasil (2013), which characterizes the absence of damaging effects on the seed at the time of sowing on the day of the treatment (Table 2).

The treatments with the insecticides imidacloprid + thiodicarb, chlorantraniliprole, cyantraniliprole, and fipronil ensured a higher value of germination compared to the seeds without coating in the periods from 0 to 60 days after treatment (DAT), which may indicate a positive effect of stimulation for this variable under the conditions analyzed. Ferreira et al. (2016) observed that soybean seeds of the NS 7494 cultivar, treated with the insecticide imidacloprid + thiodicarb associated with the fungicide metalaxyl-M + fludioxonil, exhibited a higher percentage of germination at 60 DAT compared to the control without coating. Camilo et al. (2017) obtained an increase in germination in soybean seeds of the M6972 IPRO cultivar treated with imidacloprid + thiodicarb and carbendazim + thiram at the 30 DAT storage period.

The treatments fipronil + pyraclostrobin + thiophanate-methyl, carbendazim, carboxin + thiram, and the seeds without coating did not lead to change in germination potential during the storage periods evaluated, maintaining values near $80 \%$. Santos et al. (2018) concluded that it was possible to store soybean seeds treated with fipronil + pyraclostrobin + thiophanate methyl for 150 days in cold storage without loss of germination. Pereira et al. (2011) found that treatment of soybean seeds with the fungicides tiabendazole + thiram or carbendazim + thiram exhibited germination percentages higher than $85 \%$ after 180 days of storage.

The fungicide thiophanate methyl and the insecticides chlorantraniliprole, cyantraniliprole, and fipronil led to reduction in germination at 60 and 90 DAT, respectively, indicating this to be the time at which seeds begin to suffer impairment. It is important to emphasize that germination is a fundamental process to ensure good final plant stand, and when seeds have low values for this variable, gaps in plant stand may occur and, consequently, declines in crop yield (Dan et al., 2010).

Complementing the germination test, evaluation of the FGC showed that the treatments fipronil + pyraclostrobin + thiophanate methyl, thiophanate-methyl, carboxin + thiram, chlorantraniliprole, and fipronil ensured a higher value for this variable at 60 and 90 DAT compared to the seed without coating (Table 3). Camilo et al. (2017) found an increase in the values obtained by the FGC test in soybean seeds of the M6972 IPRO cultivar treated with fipronil + pyraclostrobin + thiophanate methyl at 30 days of storage compared to the control without coating.

After storage, only the treatments fipronil + pyraclostrobin + thiophanate methyl and carboxin + thiram did not affect the FGC variable over time, maintaining levels above $70 \%$. In contrast, the treatment imidacloprid + thiodicarb proved to be

Table 2. Germination (\%) of seeds of BMX Potência RR soybean at $0,30,60$, and 90 days after treatment (DAT).

\begin{tabular}{ccccc}
\hline \multirow{2}{*}{ Active ingredient } & \multicolumn{3}{c}{ DAT } \\
\cline { 2 - 5 } control & 0 & 30 & 60 & 90 \\
\hline fipronil + pyraclostrobin + thiophanate methyl & $85 \mathrm{bA}$ & $85 \mathrm{aA}$ & $79 \mathrm{bA}$ & $84 \mathrm{aA}$ \\
thiophanate-methyl & $89 \mathrm{aA}$ & $87 \mathrm{aA}$ & $84 \mathrm{aA}$ & $87 \mathrm{aA}$ \\
carbendazim & $82 \mathrm{bA}$ & $87 \mathrm{aA}$ & $82 \mathrm{bB}$ & $81 \mathrm{bB}$ \\
carboxin + thiram & $86 \mathrm{bA}$ & $86 \mathrm{aA}$ & $84 \mathrm{aA}$ & $86 \mathrm{aA}$ \\
imidacloprid + thiodicarb & $90 \mathrm{aA}$ & $84 \mathrm{aB}$ & $84 \mathrm{aB}$ & $79 \mathrm{bB}$ \\
chlorantraniliprole & $89 \mathrm{aA}$ & $86 \mathrm{aA}$ & $85 \mathrm{aA}$ & $80 \mathrm{bB}$ \\
thiamethoxam & $85 \mathrm{bA}$ & $79 \mathrm{aB}$ & $78 \mathrm{bB}$ & $79 \mathrm{bB}$ \\
cyantraniliprole & $87 \mathrm{aA}$ & $85 \mathrm{aA}$ & $85 \mathrm{aA}$ & $78 \mathrm{bB}$ \\
fipronil & $90 \mathrm{aA}$ & $88 \mathrm{aA}$ & $89 \mathrm{aA}$ & $80 \mathrm{bB}$ \\
\hline $\mathrm{CV}$ (\%) & \multicolumn{4}{c}{$1.93^{* *}$} \\
\hline calc
\end{tabular}

*Mean values followed by the same lowercase letter in the column and by the same uppercase letter in the row do not differ from each other by the Scott-Knott test at $5 \%$ probability. ${ }^{* *}$ significant by the $\mathrm{F}$ test at $1 \%$ probability. 
more vulnerable to storage, with a value near $20 \%$ at 90 DAT. However, it should be emphasized that this lower percentage obtained in the FGC test might not be directly attributed to the lower vigor of the seed from treatment, but rather a significant reduction in germination speed brought about by the interference of the phytosanitary product applied. Certain treatments showed good final levels of germination, even with the low indices obtained in the respective test.

In regard to accelerated aging (AA), the insecticide fipronil and the mixture of fipronil + pyraclostrobin + thiophanate methyl led to the highest values, at $67 \%$ and $69 \%$, respectively. The results described corroborate the results obtained by Del Bem Junior et al. (2019); they concluded that treatment of seeds with fipronil + pyraclostrobin + thiophanate methyl led to an increase in germination of seeds under the accelerated aging test. It is noteworthy that at 60 DAT, the treatments fipronil + pyraclostrobin + thiophanate methyl, carboxin + thiram, and fipronil ensured the highest values in the AA test; the values were significantly higher than for the seeds without chemical treatment. Ferreira et al. (2016) observed that the treatment with fipronil + pyraclostrobin + thiophanate methyl brought about a higher percentage of germination in soybean seeds of the NS 7338 IPRO cultivar under the accelerated aging test at 60 days after storage.

It should be emphasized that all the treatments exhibited unsatisfactory values of germination, regardless of the period of storage, indicating low performance of the seeds in the AA test. In the AA test, the products tend to become concentrated. Along with high relative humidity and temperature, this may cause damage to the seeds, due to penetration of the products in the seed membrane (Ferreira et al., 2016). In the present study, except to the seeds without chemical treatment (which maintained their levels over time), all the treatments led to a decrease in germination percentage under the accelerated aging test over the storage period.

The results of this study corroborate those of Dan et al. (2010), who found that the insecticides fipronil, carbofuran, thiamethoxam, imidacloprid, acephate, and imidacloprid + thiodicarb reduced seed vigor after the accelerated aging test as storage time increased. Pereira et al. (2018) observed more pronounced reductions in germination and vigor after treatment of soybean seeds with the carbendazim + thiram fungicide mixture associated with the imidacloprid + thiodicarb insecticide mixture. Rocha et al. (2017) found reduction in germination levels after seeds have been submitted to the accelerated aging test as the storage period increased, with greater deterioration in treated seeds compared to the seeds without a coating.

Table 3. First germination count - FGC (\%) of seeds of BMX Potência RR soybean at 0, 30, 60, and 90 days after treatment (DAT).

\begin{tabular}{ccccc}
\hline \multirow{2}{*}{ Active ingredient } & \multicolumn{3}{c}{ DAT } \\
\cline { 2 - 5 } control & 0 & 30 & 60 & 90 \\
\hline fipronil + pyraclostrobin + thiophanate methyl & $78 \mathrm{bA}$ & $77 \mathrm{aA}$ & $41 \mathrm{~dB}$ & $33 \mathrm{cC}$ \\
thiophanate-methyl & $76 \mathrm{cA}$ & $74 \mathrm{aA}$ & $77 \mathrm{aA}$ & $78 \mathrm{aA}$ \\
carbendazim & $76 \mathrm{cA}$ & $62 \mathrm{cB}$ & $64 \mathrm{bB}$ & $60 \mathrm{bB}$ \\
carboxin + thiram & $75 \mathrm{cA}$ & $76 \mathrm{aA}$ & $37 \mathrm{~dB}$ & $31 \mathrm{cC}$ \\
imidacloprid + thiodicarb & $79 \mathrm{bA}$ & $78 \mathrm{aA}$ & $81 \mathrm{aA}$ & $76 \mathrm{aA}$ \\
chlorantraniliprole & $78 \mathrm{bA}$ & $83 \mathrm{aA}$ & $49 \mathrm{cB}$ & $20 \mathrm{dC}$ \\
thiamethoxam & $75 \mathrm{cA}$ & $60 \mathrm{cB}$ & $58 \mathrm{bB}$ & $59 \mathrm{bB}$ \\
cyantraniliprole & $70 \mathrm{cA}$ & $59 \mathrm{cB}$ & $51 \mathrm{cC}$ & $31 \mathrm{cD}$ \\
fipronil & $74 \mathrm{cA}$ & $78 \mathrm{aA}$ & $61 \mathrm{bB}$ & $37 \mathrm{cC}$ \\
\hline CV (\%) & $84 \mathrm{aA}$ & $68 \mathrm{bB}$ & $65 \mathrm{bB}$ & $64 \mathrm{bB}$ \\
\hline F & & \multicolumn{3}{c}{$34.54^{* *}$} \\
\hline
\end{tabular}

"Mean values followed by the same lowercase letter in the column and by the same uppercase letter in the row do not differ from each other by the Scott-Knott test at $5 \%$ probability. ${ }^{* *}$ significant by the $\mathrm{F}$ test at $1 \%$ probability. 
Seedling emergence in a sand bed was not different among the treatments in the first period evaluated (time 0 ), with values near $80 \%$ (Table 5). These results are similar to those obtained by Santos et al. (2018) for whom seeds of the NS 7667 IPRO soybean cultivar had germination values in sand greater than $82 \%$ for all the treatments, regardless of the combination.

Table 4. Accelerated Aging - AA (\%), after treatment of seeds of BMX Potência RR soybean at 0, 30, 60, and 90 days after treatment (DAT).

\begin{tabular}{ccccc}
\hline \multirow{2}{*}{ Active ingredient } & \multicolumn{3}{c}{ DAT } \\
\cline { 2 - 5 } & 0 & 30 & 60 & 90 \\
\hline control & $50 \mathrm{cA}$ & $48 \mathrm{aA}$ & $47 \mathrm{cA}$ & $48 \mathrm{aA}$ \\
fipronil + pyraclostrobin + thiophanate methyl & $69 \mathrm{aA}$ & $55 \mathrm{aB}$ & $58 \mathrm{aB}$ & $46 \mathrm{aC}$ \\
thiophanate-methyl & $54 \mathrm{cA}$ & $50 \mathrm{aA}$ & $47 \mathrm{cA}$ & $35 \mathrm{cB}$ \\
$\quad$ carbendazim & $40 \mathrm{dA}$ & $39 \mathrm{bA}$ & $34 \mathrm{~dB}$ & $30 \mathrm{cB}$ \\
carboxin + thiram & $61 \mathrm{bA}$ & $50 \mathrm{aB}$ & $51 \mathrm{bB}$ & $51 \mathrm{aB}$ \\
imidacloprid + thiodicarb & $53 \mathrm{cA}$ & $52 \mathrm{aA}$ & $45 \mathrm{cB}$ & $49 \mathrm{aB}$ \\
chlorantraniliprole & $48 \mathrm{cA}$ & $49 \mathrm{aA}$ & $37 \mathrm{~dB}$ & $40 \mathrm{bB}$ \\
thiamethoxam & $55 \mathrm{cA}$ & $48 \mathrm{aB}$ & $45 \mathrm{cB}$ & $45 \mathrm{bB}$ \\
cyantraniliprole & $52 \mathrm{cA}$ & $37 \mathrm{bB}$ & $24 \mathrm{eC}$ & $23 \mathrm{dC}$ \\
fipronil & $67 \mathrm{aA}$ & $51 \mathrm{aB}$ & $52 \mathrm{bB}$ & $43 \mathrm{bC}$ \\
\hline CV (\%) & & & \\
\hline $\mathrm{F}_{\text {calc }}$ & & & \\
\hline
\end{tabular}

*Mean values followed by the same lowercase letter in the column and by the same uppercase letter in the row do not differ from each other by the Scott-Knott test at $5 \%$ probability. ${ }^{* *}$ significant by the $\mathrm{F}$ test at $1 \%$ probability.

Table 5. Seedling emergence in sand (\%) after treatment of seeds of BMX Potência RR soybean at 0, 30, 60, and 90 days after treatment (DAT).

\begin{tabular}{|c|c|c|c|c|}
\hline \multirow{2}{*}{ Active ingredient } & \multicolumn{4}{|c|}{ DAT } \\
\hline & 0 & 30 & 60 & 90 \\
\hline control & $83 \mathrm{aA}$ & $77 \mathrm{bA}$ & $81 \mathrm{aA}$ & $81 \mathrm{aA}$ \\
\hline fipronil + pyraclostrobin + thiophanate methyl & $84 \mathrm{aA}$ & $83 \mathrm{aA}$ & $79 \mathrm{aB}$ & $78 \mathrm{bB}$ \\
\hline thiophanate-methyl & $85 \mathrm{aA}$ & $78 \mathrm{bB}$ & $81 \mathrm{aB}$ & $79 \mathrm{bB}$ \\
\hline carbendazim & $83 \mathrm{aA}$ & $85 \mathrm{aA}$ & $71 \mathrm{bB}$ & $76 \mathrm{cB}$ \\
\hline carboxin + thiram & $82 \mathrm{aA}$ & $81 \mathrm{aA}$ & $83 \mathrm{aA}$ & $84 \mathrm{aA}$ \\
\hline imidacloprid + thiodicarb & $81 \mathrm{aA}$ & $79 \mathrm{bA}$ & $80 \mathrm{aA}$ & $74 \mathrm{cB}$ \\
\hline chlorantraniliprole & $83 \mathrm{aA}$ & $78 \mathrm{bA}$ & $83 \mathrm{aA}$ & $71 \mathrm{cB}$ \\
\hline thiamethoxam & $84 \mathrm{aA}$ & $79 \mathrm{bA}$ & $82 \mathrm{aA}$ & $72 c B$ \\
\hline cyantraniliprole & $77 \mathrm{aA}$ & $78 \mathrm{bA}$ & $80 \mathrm{aA}$ & $77 \mathrm{bA}$ \\
\hline fipronil & $82 \mathrm{aA}$ & $78 \mathrm{bB}$ & $75 \mathrm{bB}$ & $73 \mathrm{cB}$ \\
\hline CV (\%) & \multicolumn{4}{|c|}{4.52} \\
\hline $\mathrm{F}_{\mathrm{calc}}$ & \multicolumn{4}{|c|}{$3.31^{* *}$} \\
\hline
\end{tabular}

"Mean values followed by the same lowercase letter in the column and by the same uppercase letter in the row do not differ from each other by the Scott-Knott test at $5 \%$ probability. ${ }^{* *}$ significant by the $\mathrm{F}$ test at $1 \%$ probability. 
Only the treatments carboxin + thiram, cyantraniliprole, and the seeds without chemical treatment did not lead to a reduction in the level of seedling emergence over storage time after the treatment. Seeds treated with the insecticides imidacloprid + thiodicarb, chlorantraniliprole, and thiamethoxam had satisfactory values of seedling emergence when stored up to 60 DAT, with values remaining near $80 \%$. However, at 90 DAT, these treatments, followed by the fungicide carbendazim and the insecticide fipronil, brought about the lowest values of seedling emergence.

Differences among the treatments were not found for the variables of seedling emergence speed and seedling dry matter weight (Tables 6 and 7). Dan et al. (2012) found that there was no significant difference among the insecticides

Table 6. Seedling emergence speed - ES after treatment of seeds of BMX Potência RR soybean at 0, 30, 60, and 90 days after treatment (DAT).

\begin{tabular}{|c|c|c|c|c|}
\hline \multirow{2}{*}{ Active ingredient } & \multicolumn{4}{|c|}{ DAT } \\
\hline & 0 & 30 & 60 & 90 \\
\hline control & 8.41 & 8.24 & 8.33 & 8.22 \\
\hline fipronil + pyraclostrobin + thiophanate methyl & 8.38 & 8.39 & 8.30 & 8.24 \\
\hline thiophanate-methyl & 8.10 & 8.10 & 8.15 & 8.18 \\
\hline carbendazim & 8.29 & 8.14 & 8.08 & 8.16 \\
\hline carboxin + thiram & 8.45 & 8.24 & 8.21 & 8.27 \\
\hline imidacloprid + thiodicarb & 8.32 & 8.16 & 8.30 & 8.21 \\
\hline chlorantraniliprole & 8.13 & 8.10 & 8.17 & 8.13 \\
\hline thiamethoxam & 8.29 & 8.37 & 8.45 & 8.22 \\
\hline cyantraniliprole & 8.39 & 8.26 & 8.31 & 8.25 \\
\hline fipronil & 8.28 & 8.34 & 8.35 & 8.29 \\
\hline CV (\%) & \multicolumn{4}{|c|}{4.03} \\
\hline $\mathrm{F}_{\text {calc }}$ & \multicolumn{4}{|c|}{$0.16^{\mathrm{ns}}$} \\
\hline
\end{tabular}

${ }^{n s}$ not significant by the $\mathrm{F}$ test at $5 \%$ probability.

Table 7. Seedling dry matter weight (g) after treatment of seeds of BMX Potência RR soybean at $0,30,60$, and 90 days after treatment (DAT).

\begin{tabular}{|c|c|c|c|c|}
\hline \multirow{2}{*}{ Active ingredient } & \multicolumn{4}{|c|}{ DAT } \\
\hline & 0 & 30 & 60 & 90 \\
\hline control & 1.05 & 1.10 & 0.98 & 0.88 \\
\hline fipronil + pyraclostrobin + thiophanate methyl & 1.04 & 1.20 & 0.96 & 0.94 \\
\hline thiophanate-methyl & 0.88 & 1.09 & 0.91 & 0.83 \\
\hline carbendazim & 1.05 & 1.06 & 0.83 & 0.85 \\
\hline carboxin + thiram & 0.93 & 0.97 & 0.77 & 0.80 \\
\hline imidacloprid + thiodicarb & 1.05 & 1.15 & 0.98 & 0.85 \\
\hline chlorantraniliprole & 1.08 & 1.06 & 0.89 & 0.78 \\
\hline thiamethoxam & 1.03 & 1.15 & 0.91 & 0.89 \\
\hline cyantraniliprole & 1.00 & 1.04 & 0.88 & 0.73 \\
\hline fipronil & 1.01 & 1.17 & 0.85 & 0.82 \\
\hline CV (\%) & \multicolumn{4}{|c|}{11.54} \\
\hline $\mathrm{F}_{\mathrm{calc}}$ & \multicolumn{4}{|c|}{$0.70^{\text {ns }}$} \\
\hline
\end{tabular}

${ }^{n s}$ not significant by the $\mathrm{F}$ test at $5 \%$ probability. 
thiamethoxam, fipronil, and imidacloprid in relation to the control for the variable of seedling emergence speed index. Furthermore, according to the authors, the seedling emergence speed index is an indication of seed vigor, where higher values will result in faster and more uniform seedling emergence in the field.

The results found in this study contrast with those obtained by Dan et al. (2013). Those authors found reductions in the seedling emergence speed index over the period of storage in seeds of high and of low vigor treated with the insecticide thiamethoxam. Dan et al. (2010) observed reduction in the seedling emergence speed index as the storage period increased, and this reduction was more pronounced under the treatments imidacloprid, imidacloprid + thiodicarb, carbofuran, and acephate. Pereira et al. (2011) observed that the seedling emergence speed index of seeds treated with the fungicide mixtures carbendazim + thiram or tiabendazole + thiram was significantly higher compared to the untreated seeds.

In relation to seedling dry matter weight, other authors also did not find a significant difference among treatments (Dan et al., 2012; Tavares et al., 2014; Cunha et al., 2015; Del Bem Junior et al., 2019).

Thus, seed quality, the active ingredient used in seed treatment, and the environment where the seeds will be stored must be observed, since storage must ensure maintenance of good physiological performance of the seeds by minimization of detrimental processes (Cardoso et al., 2012; Schons et al., 2018).

\section{CONCLUSIONS}

Storage time does not affect the tests of germination, first count of germination, and seedling emergence in sand of soybean seeds treated with the carboxin + thiram fungicide mixture.

The insecticide chlorantraniliprole maintains good germination and seedling emergence indices in treated soybean seeds for up to two months of storage.

The insecticide thiamethoxam has a negative effect on the physiological quality of seeds of BMX Potência RR soybean when they are stored.

For the BMX Potência RR soybean cultivar, the accumulation of seedling dry matter weight and seedling emergence speed are not affected by the insecticide and fungicide treatments tested.

\section{ACKNOWLEDGMENTS}

The authors thank the Plant Protection and Plant Production and Breeding Departments of the School of Agriculture/ Unesp, Botucatu Campus, SP, Brazil, for support in carrying out this study. The present study was performed with the support of the Higher Education Improvement Coordination - Brazil (CAPES) - Funding Code 001.

\section{REFERENCES}

ALVES, E.; AGUIAR, E.; PEREIRA, C.; MOREIRA, I.; FILHO, L.; SANTINI, J.M.K. Efeito do tratamento químico com inseticida/fungicida e polímero na qualidade fisiológica da semente de soja. Revista Científica, v.1, n.5, p.12-18, 2017. http://periodicos.unievangelica. edu.br/index.php/cientifica/article/view/2390/2046

BRASIL. Ministério da Agricultura, Pecuária e Abastecimento. Instrução Normativa $\mathrm{n}^{\circ} 45$, de 17 de setembro de 2013 . Diário Oficial da União, seção 1: 45, 25, 20. https://apps.agr.br/instrucao-normativa-no-45-de-17-de-setembro-de-2013/

BRASIL. Ministério da Agricultura, Pecuária e Abastecimento. Regras para análise de sementes. Ministério da Agricultura, Pecuária e Abastecimento. Secretária de Defesa Agropecuária. Brasília: MAPA/ACS, 2009. 395p. https://www.gov.br/agricultura/pt-br/ assuntos/insumos-agropecuarios/arquivos-publicacoes-insumos/2946_regras_analise_sementes.pdf

BRZEZINSKI, C.R.; ABATI, J.; HENNING, F.A.; HENNING, A.A.; FRANÇA-NETO, J.B.; KRZYZANOWSKI, F.C.; ZUCARELI, C. Spray volumes in the industrial treatment on the physiological quality of soybean seeds with different levels of vigor. Journal of Seed Science, v.39, n.2, p.174-181, 2017. http://www.scielo.br/pdf/jss/v39n2/2317-1545-jss-39-02-00174.pdf 
CAMILO, G.L.; CASTELLANOS, C.I.S.; SUÑÉ, A.S.; ALMEIDA, A.S.; SOARES, V.N.; TUNES, L.V.M. Qualidade fisiológica de sementes de soja durante o armazenamento após revestimento com agroquímicos. Revista de Ciências Agrárias, v.40, n.2, p.436-446, 2017. http://www.scielo.mec.pt/pdf/rca/v40n2/v40n2a16.pdf

CARDOSO, R.B.; BINOTTI, F.F.S.; CARDOSO, E.D. Potencial fisiológico de sementes de soja em função de embalagens e armazenamento. Pesquisa Agropecuária Tropical, v.42, n.3, p.272-278, 2012. http://www.scielo.br/pdf/pat/v42n3/a04v42n3.pdf

CUNHA, R.P.; CORRÊA, M.F.; SCHUCH, L.O.B.; OLIVEIRA, R.C.; JUNIOR, J.S.A.; SILVA, J.D.G.; ALMEIDA, T.L. Diferentes tratamentos de sementes sobre o desenvolvimento de plantas de soja. Ciência Rural, v.45, n.10, p.1761-1767, 2015. http://www.scielo.br/pdf/cr/ v45n10/0103-8478-cr-cr20140742.pdf

DAN, L.G.M.; BRACCINI, A.L.; BARROSO, A.L.L.; DAN, H.A.; PICCININ, G.G.; VORONIAK, J.M. Physiological potential of soybean seeds treated with thiamethoxam and submitted to storage. Agricultural Sciences, v.4, n.11, p.19-25, 2013. https://www.scirp.org/pdf/ AS_2013112814020738.pdf

DAN, L.G.M.; DAN, H.A.; PICCININ, G.G.; RICCI, T.T.; ORTIZ, L.H.T. Tratamento de sementes com inseticida e a qualidade fisiológica de sementes de soja. Revista Caatinga, v.25, n.1, p.45-51, 2012. https://periodicos.ufersa.edu.br/index.php/caatinga/article/ view/2073/pdf

DAN, L.G.M.; DAN, H.A.; BARROSO, A.L.L.; BRACCINI, A.L. Qualidade fisiológica de sementes de soja tratadas com inseticidas sob efeito do armazenamento. Revista Brasileira de Sementes, v.32, n.2, p.131-139, 2010. http://www.scielo.br/pdf/rbs/v32n2/ v32n2a16.pdf

DEL BEM JUNIOR, L.; FERRARI, J.L.; DARIO, G.; TRIBONI, Y.B.; RAETANO, C.G. Physiological potential and initial development of soybean plants as a function of seed treatment. Pesquisa Agropecuária Tropical, v.49, e55076, p.1-6, 2019. http://www.scielo.br/ pdf/pat/v49/1983-4063-pat-49-e55076.pdf

FERREIRA, T.F.; OLIVEIRA, J.A.; CARVALHO, R.A.; RESENDE, R.S.; LOPES, C.G.M.; FERREIRA, V.F. Quality of soybean seeds treated with fungicides and insecticides before and after storage. Journal of Seed Science, v.38, n.4, p.278-286, 2016. http://www.scielo.br/pdf/ jss/v38n4/2317-1545-jss-38-04-00278.pdf

MAGUIRE, J.D. Speed of germination - aid in selection and evaluation for seedling emergence and vigor. Crop Science, v.2, n.2, p.176-177, 1962. http://dx.doi.org/10.2135/cropsci1962.0011183X000200020033x

MARCOS-FILHO, J. Teste de Envelhecimento Acelerado. In.: KRYZANOWSKI, F. C.; VIEIRA, R. D.; FRANÇA-NETO, J. B. (Eds.) Vigor de sementes: conceitos e testes. Londrina: ABRATES, 1999. p.31-34.

PEREIRA, C.E.; OLIVEIRA, J.A.; GUIMARÃES, R.M.; VIEIRA, A.R.; EVANGELISTA, J.R.E.; OLIVEIRA, G.E. Tratamento fungicida e peliculização de sementes de soja submetidas ao armazenamento. Ciência e Agrotecnologia, v.35, n.1, p. 158-164, 2011. http:// www.scielo.br/pdf/cagro/v35n1/a20v35n1.pdf

PEREIRA, L.C.; MATERA, T.C.; BRACCINI, A.L.; PEREIRA, R.C; MARTELI, D.C.V.; SUZUKAWA, A.K.; PIANA, S.C.; FERRI, G.C; CORREIA, L.V. Addition of biostimulant to the industrial treatment of soybean seeds: physiological quality and yield after storage. Journal of Seed Science, v.40, n.4, p.442-449, 2018. http://www.scielo.br/pdf/jss/v40n4/2317-1545-jss-40-04-442.pdf

ROCHA, G.C.; RUBIO NETO, A.; CRUZ, S.J.S.; CAMPOS, G.W.B.; CASTRO, A.C.O.; SIMON, G.A. Qualidade fisiológica de sementes de soja tratadas e armazenadas. Revista Científica, v.1, n.5, p.50-65, 2017. http://periodicos.unievangelica.edu.br/index.php/ cientifica/article/view/2393/2049

SANTOS, S.F.; CARVALHO, E.R.; ROCHA, D.K.; NASCIMENTO, R.M. Composition and volumes of slurry in soybean seeds treatment in the industry and physiological quality during storage. Journal of Seed Science, v.40, n.1, p.67-74, 2018. http://www.scielo.br/pdf/ jss/v40n1/2317-1537-jss-40-01-67.pdf

SCHONS, A.; SILVA, C.M.; PAVAN, B.E.; SILVA, A.V.; MIELEZRSKI, F. Respostas do genótipo, tratamento de sementes e condições de armazenamento no potencial fisiológico de sementes de soja. Revista de Ciências Agrárias, v.41, n.1, p.109-121, 2018. http://www. scielo.mec.pt/pdf/rca/v41n1/v41n1a12.pdf

TAVARES, L.C.; MENDONÇA, A.O.; ZANATTA, Z.C.N.; BRUNES, A.P.; VILLELA, F.A. Efeito de fungicidas e inseticidas via tratamento de sementes sobre o desenvolvimento inicial da soja. Enciclopédia Biosfera, v.10, n.18, p.1400-1409, 2014. http://www.conhecer.org. br/enciclop/2014a/AGRARIAS/efeito\%20de\%20fungincidas.pdf 
TAYLOR, A.G.; SALANENKA, Y.A. Seed treatments: phytotoxicity amelioration and tracer uptake. Seed Science Research, v.22, n.1, p.86-90, 2012. https://doc.rero.ch/record/290748

VENKATESH, B.; GOWDA, B.; VASUDEVAN, S.N.; DODDAGOUDAR, S.R.; SUNKAD, G.; KONDA, C.R. Effect of seed coating with fungicides along with polymer on seed storability of soybean (Glycine max L. Merrill). International Journal of Chemical Studies, v.6, n.5, p.598-602, 2018. http://www.chemijournal.com/archives/2018/vol6issue5/PartK/6-4-680-588.pdf use, distribution, and reproduction in any medium, provided the original work is properly cited. 